\title{
Breast Cancer pNO(i-) TNM Finding v7
}

National Cancer Institute

\section{Source}

National Cancer Institute. Breast Cancer pNO(i-) TNM Finding v7. NCI Thesaurus. Code C88350.

Breast cancer without histological evidence of regional lymph node involvement, and with neg ative immunohistochemistry. (from AJCC 7th Ed.) 